\title{
Studying the methods for determining and maintaining sustainability of a construction firm
}

\author{
Azariy Lapidus and Ivan Abramov ${ }^{*}$ \\ Moscow State University of Civil Engineering, 26 Yaroslavskoye Shosse, Moscow, Russia
}

\begin{abstract}
Against the backdrop of the economic crisis and the complicated international situation, the government pays great attention to reforming the construction industry, creating the conditions for adapting construction firms to the existing situation and associated entrepreneurial and production risks. Concurrently, as the ever-increasing competition places higher requirements on potential participants in construction projects under state-financed and municipal contracts, new laws and regulations are being developed and improved, and bidding rules are systemized and optimized to help select the most reliable contractors resistant to various impacts. The purpose of this paper is to describe the term "sustainability of a construction firm" and to set the tasks of research into the ways of increasing sustainability of construction firms based on efficient organization of construction operations and up-to-date production and labor technology. The scientific problem suggested for review lies in ensuring guaranteed sustainability of construction firms amid uncertainties of construction operations. This paper focuses on research into and the methods for determining a correlation between sustainability of a construction firm and its resource potential that depends on a number of diverse factors.
\end{abstract}

\section{Introduction}

Construction production technology of an investment construction project is a complex integrated process which makes use of various organizational structures, organizations, enterprises, including certain components, such as: skilled personnel (managers, engineers, workers), means of mechanization, plants. To achieve a high quality result, the abovementioned components require an appropriate tool-management structure with an appropriate, integrated, organizational technological approach.

Coordination of actions between a large number of participants in the construction industry implies the emergence of factors, different in nature and frequency, which have a significant impact on participants and on construction technology per se, change it and disrupt the previously set pace. The task of this paper is to create an appropriate tool for determining the influence of external and internal factors on the structure of management in construction production. This structure includes the potential of the construction organization (enterprise) aimed to provide more accurate forecasts with regards to the behavior of an investment construction project being implemented.

Corresponding author: ivan2193@yandex.ru 
According to analysis findings, normative regulations or at least generally accepted methodological papers on the subject under review are not sufficiently studied from the scientific point of view.

For the purposes of this study, according to effective laws of the Russian Federation [1], construction firms are understood as commercial legal entities of various organizational, legal and ownership forms stipulated by laws of the Russian Federation, whose main type of activities is the performance, under construction contracts, of various construction jobs (reconstruction, technical upgrading, overhauling) of enterprises, buildings (including residential houses), structures or other facilities, and also installation, setting-up and other jobs inseparably associated with construction projects in progress, using one's own resources and/or contracted resources.

Construction operations [2] are commonly understood as a set of production processes implemented directly on a construction site and focused on construction (reconstruction, technical upgrading, overhauling) of enterprises, buildings (including residential houses), structures or other facilities, including installation, setting-up and other jobs inseparably associated with construction projects in progress during the preparation and the main periods of construction, using own resources of the construction firm and/or contractor resources.

The majority of the analyzed research papers and normative documents related to the matters of ensuring the feasibility of investment construction projects, assessment of reliability of construction firms, and raising their financial and economic sustainability offer various algorithms of formation of an operational program of a firm, an organization and the industry and balancing their production capacities, resources and organizational structure with the scopes and terms of jobs performed. The issues of operational sustainability of construction firms, their resource potential and cooperation, organizational structures of the low-level operational subdivisions and methods of their dynamic structuring associated with current risks and corresponding uncertainties of construction operations are still unexplored and require an in-depth analysis.

Thus, it can be argued that the selected subject of this research is practically relevant and calls for theoretical justification.

\section{Results and discussion}

As far as the tasks of construction management, economics, organization and technologies are concerned, the notion of "sustainability of a firm" remains undetermined in terms of normative or generally accepted applications. Various author define the terms of "financial sustainability" [3,4], "economic sustainability" [5,6], "strategic financial sustainability" [7,8], "organizational and economic sustainability" [9,10], etc. in accordance with the groups of impacts reviewed for assessing the sustainability indicators.

Inasmuch as the research problem raised by the author presumes an assessment of how the sustainability of a construction firm is affected by current risks and uncertainties of construction operations (alongside with other groups of factors), the author considers the following definition to be the most appropriate one in line with the tasks in hand:

A sustainable construction firm is one able to operate efficiently in unstable, uncertain competitive market conditions (technology sustainability, supply and sale sustainability, financial sustainability, etc.). 


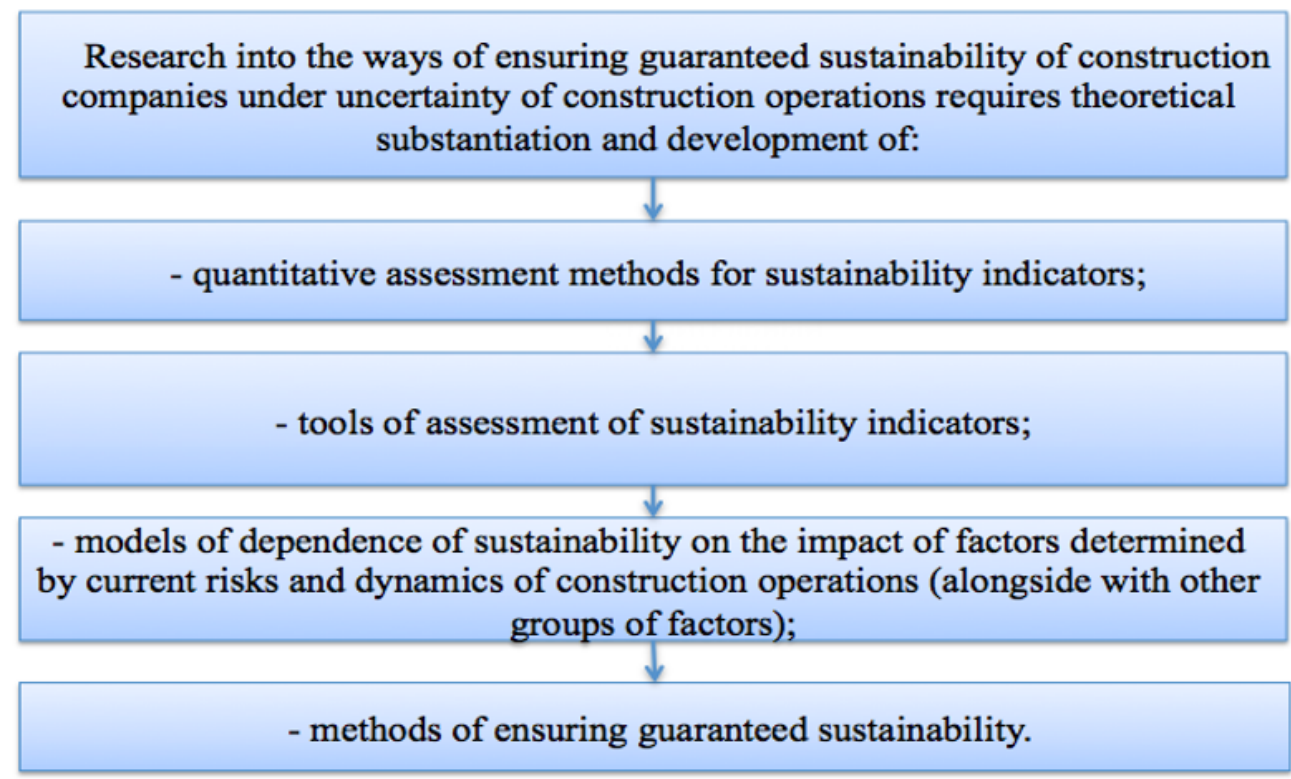

Fig. 1. Description of methods to determine the sustainability of a construction firm

The main research hypothesis is defined as follows:

A guaranteed level of sustainability of a construction firm is attained by the ability of the construction management system to adapt to changes in production loads from minimum values to simultaneous implementation of several projects, including large-scale projects. Such operational conditions require a corresponding conceptual model of a systemic and dynamic management structure of a construction firm based on determination of the basic minimum of permanent administrative staff and line managerial staff, an optimum level of the company's own technical, technological and HR resources, as well as rational cooperation, that in totality make it possible to develop the production potential up to reasonably necessary values $[11,12,13,14]$.

\section{Method}

The authors suggest studying and reviewing a model of dependence of a company's sustainability on its resource potential indicator (RPI) which, in turn, depends on a number of factors. A company's RPI has a direct impact on the sustainability of a construction firm and, accordingly, interim and final qualitative outcome of an implemented construction project or projects.

As a matter of priority, it is important to specify the firm's main resources (equipment), give them an expert assessment and, using the model (1), identify the construction firm's resource potential indicator $[15,16,17]$ for subsequent evaluation of its sustainability.

Let us specify and evaluate the significance of each FAR (factors affecting the result).

Availability of equipment, machinery and duly qualified and specialized personnel:

- Availability of skilled personnel in this firm $(\mathrm{FAR}=+2)$;

- Absence of skilled personnel in this firm $(\mathrm{FAR}=-2)$;

- Availability of facilities: offices $(+1)$, warehouses $(+1)$, vehicle fleet $(+1)$, concrete plants $(+1)\left(\sum \mathrm{FAR}=+4\right)$;

- Absence of facilities: offices (-1), warehouses (-1), vehicle fleet (-1), concrete plants (1) $\left(\sum \mathrm{FAR}=-4\right)$; 
- Availability of specialized construction machinery and equipment: tower and crawler cranes $(+1)$, concrete pumps $(+1)$, mobile cement stations $(+1)$, excavators $(+1)$, bulldozers $(+1)$, graders $(+1)$, rollers $(+1)\left(\sum \mathrm{FAR}=+7\right)$;

- Absence of specialized construction machinery and equipment: tower and crawler cranes (-1), concrete pumps (-1), mobile cement stations (-1), excavators $(+1)$, bulldozers $(+1)$, graders $(+1)$, rollers $(+1)\left(\sum \mathrm{FAR}=-7\right)$;

- Availability of means of transportation: dump trucks $(+1)$, low bed trucks $(+1)$, concrete mixer trucks $(+1)\left(\sum \mathrm{FAR}=+3\right)$;

- Absence of means of transportation: dump trucks (-1), low bed trucks (-1), concrete mixer trucks $(-1)\left(\sum \mathrm{FAR}=-3\right)$.

Index $\mathrm{k}$ as an indicator of the firm's financial standing is taken to be equal to 0 , if the firm under review is in arrears in the payment of wages or taxes. Index $\mathrm{k}$ is taken to be equal to 1 , if all required documents in confirmation of absence of arrears are provided.

As a result, the information obtained for RPI determination and characterizing the significance of each FAR, should be reflected in an overall mathematical model $[18,19,20]$.

A construction firm's resource potential (CRP) is calculated according to the following formula:

$$
\mathrm{CRP}=k \sum_{i=1}^{n} V_{i}=k\left(V_{1}+V_{2}+\ldots+V_{n}\right),
$$

where $V_{i}$ is the aggregate of FARs and $\mathrm{k}$ is the financial standing index

Assessment of a construction firm's sustainability:

$-16 \leq \mathrm{CRP}<1-$ this firm has a low sustainability involving unpredictable risks that may arise in construction operations;

$1 \leq \mathrm{CRP} \leq 8$ - this firm has a moderate sustainability (resistance to all possible impacts) involving certain risks that may arise in construction operations;

$8<$ CRP $\leq 16$ - this firm is sustainable and can be planned for in the organization of construction operations.

This research into an indicator of a construction firm's resource potential has resulted in theoretical recommendations for an efficient assessment of a firm's sustainability.

\section{Conclusions}

The problem under review can be solved through theoretical substantiation, development and practical implementation of integrated methods that can be used when forming rational, systemic and dynamic management structures within construction firms engaged in the construction projects in the conditions of uncertainty.

This scientific task is of great social and economic importance for Russian construction firms. Theoretically substantiated engineering and organizational solutions resulting from this research will make a significant contribution to the construction industry development and represent a qualitative step forward in the organization of operations conducted by construction firms and acceleration of their scientific and technical progress.

This work was financially supported by Ministry of Science and Higher Education of the Russian Federation (\#NSh-3492.2018.8).

\section{References}

1. Civil Code of the Russian Federation; Town Planning Code of the Russian Federation; Federal Law No.39-FZ On Investment Activities in the Russian Federation in the Form of Capital Investment, (1999). 
2. Construction Regulations 48.13330.2011 Organization of Construction. Revised edition of SNiP12-01-2004 (2004).

3. N.Yu. Sukhina, Yu.V. Leshova, V.O. Primakova. Management of a company's financial sustainability in the context of a financial crisis. A collection of articles of international research-to-practice conference Scientific Research and Development in the Globalization Era, (2016).

4. A.V. Zakharkina, Financial sustainability of a company. Notion through Essence // Start in Science, 5, 149-150 (2016).

5. A.O. Nedosekin, E.I. Reishakhrit, Revisiting the issue of defining the category of "economic sustainability" in raw materials industries, 58-5 (2017).

6. S.Yu. Pleshkov, Economic sustainability of a construction company's operations: calculation and assessment methodology: [study guide]; Ministry of Education and Science of the Russian Federation, The Ural Federal University, Publishing House of the Ural Federal University, 59 (2014).

7. I.A. Pulotov, S.V. Gubarkov, Strategic analysis of a company's financial sustainability // Economics: Yesterday, Today, Tomorrow, 6, 27-38 (2016).

8. A.V. Pikhtareva, Strategy formation for a company's financial sustainability // Theory and practice of social development, 11 (2012).

9. E.V. Jamai, A.S.Zinchenko, M.V. Yudin, Methods of assessment of organizational and economic sustainability and manageability of machine building companies under restructuring, Bulletin of the University, 13 (2015).

10. Morozenko A.A. Reflex-adaptive organizational structure of investment and construction projects. Dokt. Diss. Moscow, 2013. (In Russian)

11. Morozenko A.A. Sinergeticheskiy podkhod k povysheniyu gibkosti struktury investitsionnno-stroitel'nogo proekta na osnove kriteriya ustoychivosti Naykvista Mikhaylova [Synergetic Approach to Improvement of the Structural Flexibility of an Investment Construction Project on the Basis of the Nyquist - Mikhailov Criterion of Stability]. Vestnik MGSU [Proceedings of Moscow State University of Civil Engineering]. 2012, no. 8, pp. 203-206.

12. I.L. Abramov, T.Y. Poznakhirko, A. Sergeev, The analysis of the functionality of modern systems, methods and scheduling tools, MATEC Web of Conferences, 86 (2016).

13. Dmitriy Topchiy and Andrey Tokarskiy Formation of the organizational-managerial model of renovation of urban territories, 2018 Matec Web Conf. 196. 04029 https://doi.org/10.1051/matecconf/201819604029

14. Morozenko A. A. Stability as complex characteristic determining the ability of ensuring the implementation of investment and construction projects // Internet-Vestnik VolgGASU. Ser.: Polythematic. 2011. Vol. 4 (19).

15. Lapidus A., Abramov I, Implementing large-scale construction projects through application of the systematic and integrated method. FORM2018 (XXI International Scientific Conference "Construction the formation of living environment") 2018г. IOP Conf. Ser.: Mater. Sc i.Eng. 365062002 https://doi.org/10.1088/1757899X/365/6/062002

16. Lapidus AA., Abramov I.L., Systemic integrated method for assessing factors affecting construction timelines. MATEC Web of Conferences 193, 05033 (2018) https://doi.org/10.1051/matecconf/201819305033

17. A. Fini, T. Rashidi, Incorporating Multiskilling and Learning in the Optimization of Crew Composition, Journal of Construction Engineering and Management, 5 (2015).

18. Lapidus A.A., Abramov I.L., Formation of production structural units within a construction company using the systemic integrated method when implementing highrise development projects. HRC 2017 (HIGH-RISE CONSTRUCTION-2017) E3S Web of Conferences 33. 03066 https://doi.org/10.1051/e3sconf/20183303066 
19. Abramov I. L., Formation of integrated structural units using the systematic and integrated method when implementing high-rise construction projects HRC 2017 (HIGH-RISE CONSTRUCTION-2017) E3S Web of Conferences 33. 03075 https://doi.org/10.1051/e3sconf/20183303075.

20. L. Floreza, J. Cortissoz, Defining a mathematical function for labor productivity in masonry construction: A case study. Procedia Engineering, 164, 42-48 (2016) 